\title{
The Effect of Social Work Environment on Employee Productivity in Manufacturing Company in Indonesia
}

\author{
Sumiyati, Masharyono, Kevin Fazar Pratama, Ridwan Purnama \\ Universitas Pendidikan Indonesia \\ Bandung, Indonesia \\ masharyono@upi.edu
}

\begin{abstract}
The ability of a company to survive and exceed in a dynamic environment based on approach to organizational decision making. Considers a company`s ability to make a profit without sacrificing the resources of its employees, community, environment. The purpose of this research was the of social work environment on employee productivity. Methods used the explanatory survey. The subject in this study was 113 employees. The survey was complicated by questioner and analysis techniques data using with SPSS. The results showed social work environment on employee productivity. There for, the company wants to increase the productivity of employees, one way is correct or create a social work environment conducive.
\end{abstract}

Keywords - social work environment, employee productivity, and manufacturing

\section{INTRODUCTION}

In this global era, the business competition among the firms are so tight, including in inn field. The serve in this field need special attention, because it's about consumer's satisfaction, so good moral workers, professional, discipline and responsible in doing his duty are needed. These term are needed in increasing work productivity, serve quality, and competition power in our own country and abroad. But, in fact, there are still workers that less in work productivity [1].

Experiments have done so that can increase productivity, almost any organization has launched a program to increase productivity, but this is still the main problem in by the company now [2]. Implementation or otherwise of interest of a company can be determined by the employee's productivity for the employee's productivity is not to be overlooked and are important steps to achieve a predetermined goal. Productivity is a position where an organization accomplish its objectives by changing the input to output at the lowest cost [3] [4]. Decreased employee productivity open discussion and debate in almost every organization, so it is still important employee productivity analysis conducted [5].

There is a lot of discussion and analysis of the importance of productivity growth to accelerate economic growth, their analysis of the situation that can support or hinder the improvement of productivity [6]. Efforts to improve the productivity of employees, namely 1) developing and provide a social work environment a better employee, a good physical working environment 2) Tidiness storage of raw materials and finished 3) working facilities [7]. Social work environment is one of the factors that affect employee productivity [8]. The purpose of this study was to determine the effect of Social Work Environment on Employee Productivity.

\section{LITERATURE REVIEW}

Organizations need human resources who can work efficiently and effectively and the organization must be able to take over management of employee well. The employee's productivity is a measure of performance efficiency and effectiveness [9].

Factors that affect the productivity of labor, namely 1) developing and provide a social work environment a better employee, a good physical working environment 2) Tidiness storage of raw materials and finished 3) working facilities [7].

Create an environment of social work to make productive employees are essential to increase profits for the organization [10]. Social work environment and good communication in the workplace have an effect on worker welfare, health, morals, efficiency and productivity. Then the social work environment plays an important role in the production process, a good social working environment is needed by the employee or employees at all levels of management to improve the productivity of employees [11]. Productivity is affected by ability, motivation, and quality work of life [12].

\section{RESEARCH METHODOLOGY}

The object of this study social work environment and employee productivity. But the subject of study is employees. The population of the research is 113 employees PT. Joongang Food Sumedang Indonesia. Data Analysis techniques used use linier regression with SPSS. The hypothesis in this research are there are significant social work environment on employee productivity.

\section{THE RESULTS OF RESEARCH}

Simple regression testing results obtained regression equation as follows: $\mathrm{Y}=5.814+0.815 \mathrm{X}$. The constant of 5.814 states that if there is no social work environment and the quality of working life $(X=0)$ then the employee's productivity is worth 5.814 a unit value. The regression coefficient of the unit value of 0.815 means that any increase in the social work environment will increase the productivity of employees amounted to 0.815 of the unit value and vice versa if the decline in the productivity of employees, social work environment will reduce the productivity of employees amounted to 0.815 a unit. 
Hypothesis testing results indicate that there are significant social working environment on work productivity by $47 \%$. While the rest of 53\% influenced by other factors such as quality work of life [11].

Based on empirical research results in the form of social work environment on employee productivity, employee productivity is positively influenced by the social work environment. Social work environment and good communication in the workplace have an effect on worker welfare, health, morals, efficiency and productivity. One key to the success of a company is how to make social work environment for the better, so as to improve the productivity of employees [12].

Furthermore, creating a social work environment to make productive employees are essential to increase profits for the organization [10]. In an effort to increase the productivity of employees need to develop and provide a social work environment better employees, good physical work environment as well, such as lighting a clear, neatness storage of raw materials, finished and work facilities [7]. Factors that determine productivity, namely 1) the attitude of work, such as readiness to work in turns (shift work), may receive an additional tasks and working in teams. 2) The level of skill, which is determined by the level of education and training in management and supervision as well as skills in industrial engineering. 3) The relationship between labor and head of the organization that is reflected in a joint effort between management and labor organizations to improve productivity through quality control circles (quality control circles) and the committee on employment ahead. 4) Management of productivity, the efficient management of the resources and work systems to achieve increased productivity. 5) The efficiency of labor such as: workforce planning and additional tasks [13]. The ability of a company to survive and exceed in a dynamic environment based on approach to organizational decision making. Considers a company`s ability to make a profit without sacrificing the resources of its employees, community, environment [14].

\section{V.CONCLUSIONS AND SUGGESTIONS}

Based on the description of theory and research has been done using descriptive analysis and verification as well as simple linear regression between social work environment on employee productivity production division of PT. Joongang Food in Sumedang, it can be deduced that the t test results showed that the social work environment positive effect on employee productivity, where the increase in social working environment will affect the increased employee productivity.

\section{REFERENCES}

[1] Prasetyo E, Wahyuddin M. Effect of Job Satisfaction and Motivation Against Employee Productivity Riyadi Palace Hotel in Surakarta. Universitas Muhammadiyah Surakarta. 2004.

[2] Neha Priyanka. Motivation: a driving tool to employee productivity.2014.

[3] Robbins, Stephen P. dan Timothy A. Judge. 2013. Organizational Behavior 15th edition. Prentice Hall: Pearson Education. Inc

[4] Tjutju Yuniarsih dan Suwatno. Human Resources Management. Bandung: Alfabeta.2008

[5] Syed Mubasher Hussain Navi, et al. Job Stress and Employees' Productivity: Case of Azad Kashmir Public Health Sector. 2013.

[6] Tamilselvan.R dan Bhavani K. Impact of Industrial Relations on Employee Productivity. 2010.

[7] I Wayan Senata et al. Influence of Work Environment Employee Productivity Against UD. Kembang Sari Badung Regency in 2012. 2014.

[8] Sutermeister RA. People and productivity. 1976.

[9] Robbins, Stephen P. dan Mary Coulter. Management 11th edition. New Jersey : Pearson Education. Inc. 2012

[10] Chandrasekar, K. 2011. Workplace Environment and Its Impact on Organisational Perfomance in Public Sector Organizaions

[11] Gomez-Mejia, Luis R and David B. Balkin and Robert L. Cardy. Managing Human Resources. United States: Pearson Education Inc., publisihing as Prentice Hall.2012.

[12] Emmanuel Majekodunmi Ajala. The Influence of workplace environment on workers walfare, performance and productivity volume 12 no 1, June 2012.

[13] Sedarmayanti. orking Procedures and Work Productivity: An Overview Of Ergonomic aspects Or Link Between Man With Environment Works. Third Matter. Bandung: Mandar Maju. 2011.

[14] Ferreira A, Du Plessis T. Effect of online social networking on employee productivity.2009 